
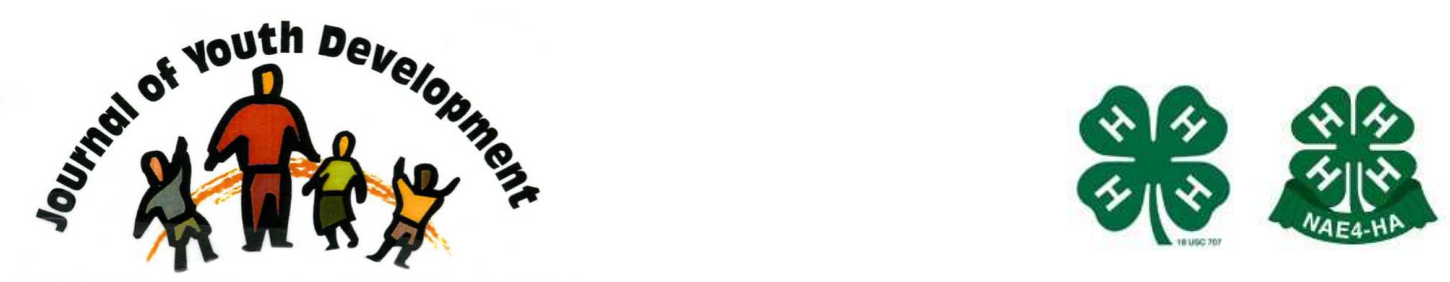

Bridging Research \& Practice

\title{
Resource Review: \\ The Annie E. Casey Foundation 2010 KIDS COUNT Data Book State Profiles of Child Well-Being
}

\author{
Patricia Dawson \\ Oregon State University \\ Pendleton, OR
}

patricia.dawson@oregonstate.edu 


\title{
JOURNAL OF YOUTH DEVELOPMENT \\ bridging research and practice

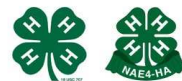

Bridging Research \& Practice

\section{Resource Review: \\ The Annie E. Casey Foundation 2010 KIDS COUNT Data Book State Profiles of Child Well-Being}

\author{
Patricia Dawson \\ Oregon State University
}

\begin{abstract}
The 2010 KIDS COUNT Data Book: State Profiles of Child Well-Being is an excellent resource for youth development professionals. The Data Book, prepared by the Annie E. Casey Foundation, provides national as well as state-by-state information on the conditions of America's children and families. Ten key indicators of child well-being are utilized for the state rankings. In addition, the book includes an Appendix highlighting 10 years of state-by-state rankings using key indicators of child well-being.
\end{abstract}

\section{Introduction}

Youth Development professionals looking for a compilation of data on children and families in the United States with state rankings will find the "2010 KIDS COUNT Data Book: State Profiles of Child Well-Being" (2011) to be particularly helpful. The resource is designed to provide ongoing benchmarks which show how states have regressed or advanced over time. Users of the resource will also be able to compare status of children in their states with those in other states.

The resource reports on key indicators of a child's well-being and compares data from 2000 and 2007/2008. The 10 key indicators reported in the study include:

- Percent low-birth weight babies

- Infant mortality rate (deaths per 1,000 live births)

- Child death rate (deaths per 100,000 children ages 1-14)

- Teen death rate (deaths per 100,000 teens ages 15-19)

- Teen birth rate (births per 1,000 females ages 15-19)

- Percent of teens not in school and not high school graduates (ages 16-19)

- Percent of teens not attending school and not working (ages 16-19) 
- Percent of children living in families where no parent has full-time, year-round employment

- Percent of children in poverty (income below $\$ 21,834$ for a family of two adults and two children in (2008)

- Percent of children in single-parent families

Comparative data is presented for the 10 key indicators including state-level maps of each indicator as well as the ten highest and lowest ranking states for each study.

Easy to use Tables and Charts highlight significant summary results. The individual state-level data is particularly valuable as youth professional prepare program justifications or funding proposals.

\section{Limitation}

While data for the key indicators is drawn from federal government statistical agencies it is important that readers recognize that many of the indicators are derived from samples and may contain some random error. Historical data for each state is available at the KIDS COUNT Data Center and may provide a clearer assessment of changes within a particular state.

\section{Highlights}

The 2010 KIDS COUNT Data Book also includes an Appendix featuring Overall Ranks from 2000 through 2008 for each state, using the same consistent set of indicators that are utilized in the 2010 report. Readers will find the charts particularly helpful in see how their state has improved on ranking over the past 10 years.

\section{Obtain a Copy}

The 60 page 2010 KIDS COUNT Data Book can be located at the Annie E. Casey Foundation website www.aecf.org. In addition, readers can access data quickly from iPhone, Blackberry or any Smartphone at Mobile.kids.count.org.

\section{Website}

The Annie E. Casey Foundation. http://datacenter.kidscount.org/DataBook/2010/Default.aspx

(C) Copyright of Journal of Youth Development Bridging Research and Practice. Content may not be copied or emailed to multiple sites or posted to a listserv without copyright holder's express written permission. However, users may print, download or email articles for individual use. 